\title{
CAPACITY BUILDING OF COMMUNITY-BASED REHABILITATION TO ACCESSIBILITY OF PERSONS WITH DISABILITIES
}

\author{
Annisa Nur Fathin ${ }^{1}$, R. Enkeu Agiati ${ }^{2}$, Neni Kusumawardhani ${ }^{3}$ \\ ${ }^{1}$ Sekolah Tinggi Kesejahteraan Sosial Bandung \\ fathin_annisa@yahoo.co.id \\ ${ }^{2}$ Sekolah Tinggi Kesejahteraan Sosial Bandung \\ agiatienkeu@yahoo.co.id \\ ${ }^{3}$ Sekolah Tinggi Kesejahteraan Sosial Bandung \\ nenikusumawardhani@ymail.com
}

\begin{abstract}
Capacity building is the capability enhancement process of the Community-Based Rehabilitation (RBM) caretaker in providing services to persons with disabilities, so they could access their needed services. The achievement of capacity building for RBM management can ultimately implement Sundanese proverbs such as silihasah, silihasih and silihasuh.The purpose of this research is to study Capacity Building of Community-Based Rehabilitation to Accessibility of Persons with Disabilities in Cibiru Wetan Village, Cileunyi Sub-district, Bandung Regency. The research method used is qualitative with action research design. Data source used is primary data source and secondary data source. The data collection techniques used were in-depth interviews, participant observation, documentation study, and Focus Group Discussion (FGD). Data validity checking technique used is credibility, transferability, dependability, and confirmability. Furthermore, the results of this study were analyzed by qualitative analysis techniques. The results showed that the capacity building of RBM Cibiru Wetan caretaker enhances the capability of RBM caretaker to provide services to persons with disabilities.Shown by RBM Cibiru Wetan caretaker in providing services to identify the needs and problem of persons with disabilities, assessment, planning and working matrix, improving the RBM management, as well as recording the handling of cases of persons with disabilities. The RBM caretaker capacity impacts the quality of RBM services to be comprehensive and based on social work.
\end{abstract}

Keywords: accessibility, capacity building, Community-Based Rehabilitation

\section{Introduction}

Persons with disabilities are one of the issues that get the attention of the government. This is evidenced by the existence of government policies that leads to the realization of inclusive society.

The paradigm of persons with disabilities, originally institutional-based, has now turned to community-based and rights. This is in accordance with the paradigm of persons with disabilities ave switched from medical model to social model, which according to Jewell (2010) disabled persons in the social model paradigm is:

Persons with disabilities occur due to incompatibility between individuals and the environment. This is due to individual differences and because the environment does not adapt to accommodate one's reach.

The current definition of persons with disabilities refers to the interaction of 
individuals with the environment, a common ground of thought that discrimination is not only the responsibility of the individual, but also the responsibility of the family, government, and society.

The rights of persons with disabilities are set forth in Law No. 8 of 2016 on Persons with Disabilities. The accessibility rights set forth in Law No. 8 of 2016 concerning Persons with Disabilities article 18 mean that persons with disabilities have accessibility to utilize appropriate public and accommodation facilities as a form of accessibility for individuals. Accessibility means the convenience felt by personswith disabilities to reach services based on equal opportunity. The areas of accessibility aredivided into areas of health, education, employment, transportation, infrastructure, public facilities, and so forth. These areas are also divided into physical and nonphysical accessibility.

However, the rights to accessibility of disabled people remains a great concern. Persons with disabilitie are still difficult in reaching the services that exist in the environment. Persons with disabilities find it difficult to obtain facilities in the ward because people have not noticed the needs of people with disabilities such as unrestricted infrastructure for wheelchair users, sidewalks that do not have signs for persons with disabilities, and persons with disabilities have not received priority in obtaining services.

In fact, people with disabilities still have to adjust to the environment, not the other way around. Whereas Law Number 8 Year 2016 on Persons with Disabilities has mandated that a person is said to be disability when the environment does not provide opportunities for persons with disabilities to interact and participate fully based on equal opportunity. Therefore, persons with disabilities are not accessible because the environment has not supported, either in the form of physical or non-physical accessibility.

Accessibility is difficult experienced by people with disabilities in Indonesia, amounting to $6,008,640$ people from $244,919,000$ people in Indonesia based on Pusdatinakerdata 2014. Persons with disabilities in West Java Province based on data Ministry of Social Affairs in 2011 which amounted to 153,909 people were not entirely accessed to service.

Bandung Regency is one of the regencies in West Java Province which has 2,008 people with disabilities. From the number of persons with disabilities in some villages in Bandung regency, the number of persons with disabilities in CibiruWetan Village is relatively more than in other villages, is 97 people consisting of physically disabled persons, 41 sensory disabilities, 30 intellectual disabilities, 7 mental disabilities, and 6 dual disabilities. This number is based on practicum data obtained in 2016. This number of persons with disabilities shows that persons with disabilities in CibiruWetan Village need special attention.

Based on the results of the lab, people with disabilities in CibiruWetan Village have some problems. Most of the perceived problems are accessibility issues. Accessibility that becomes a problem in CibiruWetan Village is the accessibility of health, employment, infrastructure, and transportation. Persons with disabilities in CibiruWetan Village, if they get sick, they must use a private vehicle or motorcycle taxi to seek a doctor or health center.

In addition to health services, work services were difficult to reach by people with disabilities in the CibiruWetan Village. The existence of companies in CibiruWetan Village does not mean that persons with disabilities get decent jobs. This is due to the low level of education of persons with disabilities, so the skills of persons with disabilities are limited. Infrastructure accessibility is not sufficient for persons with disabilities, especially infrastructure facilities available at home and public facilities. Persons with disabilities in CibiruWetan Village find it difficult to carry out daily activities independently because the infrastructure does not support the mobility of persons with disabilities.

Adequate accessibility is not only the responsibility of individual persons with disabilities, but also the responsibility of the environment. CibiruWetan Village Government has a share in making policy or 
program so that people with disability in CibiruWetan Village get the same opportunity as CibiruWetan villager in general. In addition to the important role of village government apparatus, the community also has responsibility by forming Community-Based Rehabilitation (RBM).

RBM is one of the institutions formed from the community, by community, and for the community. RBM was formed on the basis of community responsibility and based on the local wisdom of the Sundanese tribe who have the principles of "silihasih, silihasah, and silihasuh" between fellow, also Sundanese tribes have the habit of mutual help and cooperation. Therefore, the RBM was formed to help the people who have limitations as a form of public awareness of persons with disabilities.

RBM are established at the village or village level in each district / city. One of services undertaken by RBM is the provision of accessibility services to persons with disabilities. This is supported by the meaning of RBM according to EttyPadmiati and Sri Kuntari (2011) that the main concept of $\mathrm{RBM}$ is community empowerment, meaning that the services provided within the family and community utilize the resources and funds in the community.

Based on the results of practice, it is known that RBM CibiruWetan is driven by people who care about people with disabilities. This is in accordance with the Sundanese culture that still uphold mutual cooperation, where mutual support among the citizens is to realize the welfare of other citizens, in this case is persons with disabilities.

Activities that have been undertaken in order to improve services for persons with disabilities include routine therapy services every 4th week, home visit to see the condition of people with disability, and the provision of tools to people with disability through outreach to districts and social institutions. RBM has done a series of activities, but in the process has not run as a whole because the service process has not been comprehensive, the management of RBM has not been comprehensive, and the cooperation of RBM together with other parties has not been integrated.

The problems faced by RBM show that RBM requires capacity building. Capacity building according to JeniviaDwiRatnasari, et al (2013) is an effort to strengthen individual, group or organizational capacities through the development of ability, skill, potential and talent and mastery of competencies so as to be able to overcome the challenges of rapid and unexpected changes. Capacity Building by TotokMardikanto and PoerwokoSoebiato (2015: 69) is a process of enhancing individual, group, organizational and other institutional capacities to understand and implement sustainable development.

The purpose of strengthening the capacity is so that RBM can provide services to people with disabilities as a whole and integrated. One of them is RBM can perform accessibility services to people with disabilities. The achievement of capacity building for RBM management can ultimately implement Sundanese proverbs such as silihasah, silihasihandsilihasuh.

Based on the description, the research conducted is about "Capacity Building of Community-Based Rehabilitation to Accessibility of Persons with Disabilities in CibiruWetan Village,CileunyiSubDistrict,Bandung Regency". The problem is focused on: 1) how are the characteristics of the subject ?, 2) how to describe the Cibiru Wetan Community-Based Rehabilitation service before capacity building? 3) howis the implementation of Community-Based Rehabilitation capacity building to accessibility of persons with disabilities, and 4) how is the description of the CibiruWetan Community-Based Rehabilitation service after capacity building?

The objectives of this study were to examine: 1) the characteristics of the subjects, 2) description of CibiruWetan Community Based Rehabilitation services before capacity building, 3) implementation of Community-Based Rehabilitation capacity building on accessibility of persons with disabilities, and 4) description of the CibiruWetan Community Based 
Rehabilitation service after capacity building.

\section{Method}

The design used in this research is qualitative research using action research. Bogdan and Taylor in Lexi Moleong (2007: 8) states that qualitative research is a research procedure that produces descriptive data in the form of written or oral words of the people and behavior that can be observed. The action research according to Stringer, Ernest T (2007: 19) should be based on local studies that focus on the need to understand how things happen, not just what happens, and to understand the ways in which stakeholders perceive, interpret, and respond activities related to the issue under investigation.

Action research is an attempt to try out ideas into practice to improve or change something in order to have a real impact on the situation. Strengthening the capacity of RBM on accessibility of persons with disabilities in CibiruWetan Village, Cileunyi Sub-district, Bandung Regency is an attempt to improve a social situation in order to create a community of inclusion to persons with disabilities.
Researcher facilitate board of RBM, persons with disabilities, parent's persons with disabilities, village apparatus, and company in Cibiru Wetan to make a collaborative and participative change. Therefore, this study focuses on participatory and collaborative research, where the cooperation between researcher and participants who actively participate in designing action research, collecting data, analyzing data, and providing interpretation and determining the action.

The modification of the research design according to the research flow of Community-Based Rehabilitation Capacity Building on Accessibility of Persons with Disabilities is as follows:
Initial Reflection Stage

1. RBM has not provided comprehensive services to people with disabilities

2. Accessibility for persons with disabilities needs to be improved

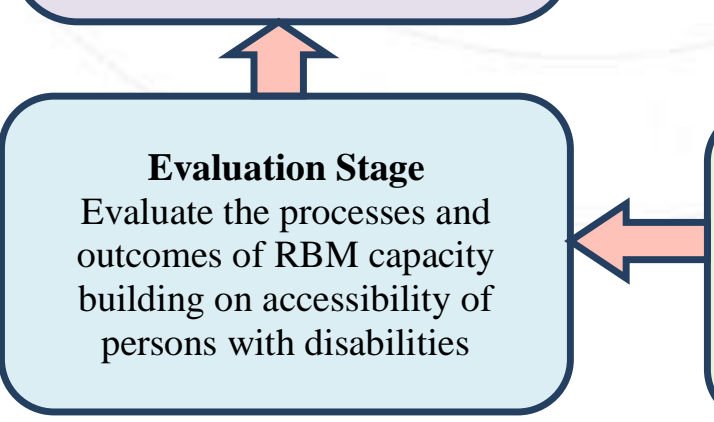

Chart 1. Research Flow
Planning Stage

Prepare a plan based on the results of initial reflection

Implementation Phase Implement RBM capacity building on accessibility of persons with disabilities 
The research stages consist of stage I, the initial reflection, is conducting assessment of the results of the assessment on the condition of RBM on the provision of accessibility services to persons with disabilities; stage II, planning the implementation of RBM capacity building on the accessibility of persons with disabilities; stage III, implementation of RBM capacity building on accessibility of persons with disabilities; and IV, evaluation of the process and results of the implementation of RBM capacity building in improvingaccessibility of persons with disabilities.

Source of data in this research consist of primary data source and secondary data source. Primary data sources were obtained from 3 RBM managers through in-depth interviews, participant observation, and Focus Group Discussion (FGD). The technique to determine the subject is by using purposivesampling, where the determination of RBM board which made as subject is adjusted with some criteria.

The subjectsin this study consisted of three RBM managers, namely FD, E, and EK who have various age and education level. In addition to the board of RBM CibiruWetan also in this study determined informants, namely parents with disabilities and village officials who become supporters in this study.

FD is the RBM chairman. FD 42 years old, 42 years old is the productive age, where at this productive age, someone has an idea and oriented to the work that makes RBM better. Supported by her bachelor education, FD can reflect the needs of people with disabilities will be serviced by RBM. FD works as a housewife, it also makes FD has a fairly good commitment and always contribute to the development of RBM.

The next research subject is $\mathrm{E}$, subject $\mathrm{E}$ is the RBM treasurer who has the main duty and function in providing services for persons with disabilities. The age of $\mathrm{E}$ is 50 years old, age 50 is classified as productive age, where at this age one is oriented towards work, so the subject E also has an orientation to work and is motivated to work hard especially in providing services to persons with disabilities. The level of $\mathrm{E}$ subject education is elementary school; the level of elementary education can be said relatively low.If one's education is low, then it cannot reflect the needs of family members or others. However, subject E who has an elementary education level does not become a barrier to active role in RBM.

The next subject is EK, the subject of EK served in RBM as a board that has responsibility in the social field. The subject age of EK is 57 years old, 57 years of age belonging to productive age, where the subject of EK has an orientation towards the work that makes the subject of EK always motivated to provide the best service to persons with disabilities. This is also supported by the work of EK subjects as housewives who make EK subject has enough spare time, so the responsibility in RBM was run well by trying to always attend the activities organized by RBM. The level of education of EK subject is junior high, low education affects the knowledge and skills of a person, but not on the subject of EK. The subject of EK actually has adequate skills due to his experience as PKK cadres since 2011. The task as a cadre carried by the subject of EK provides the knowledge and skills that can be applied in $\mathrm{RBM}$ in providing services to persons with disabilities.

Based on the characteristics of the three subjects indicated that the three subjects made it possible to provide RBM services to persons with disabilities, although the three study subjects had a diversity of age and education. Therefore, to provide services to persons with disabilities that are more comprehensive and integrated, it is necessary to strengthen the capacity for RBM CibiruWetan board.

While the secondary data source obtained through study documentation. Secondary data sources include documents relating to RBM and persons with disabilities with accessibility problems.

The data collection technique is done by using in-depth interview, participant observation, documentation study, and Focus Group Discussion (FGD). While the examination of data validity is done by 
credibility test, transferability test, dependability test, and conformability test. Data analysis is done by data reduction process, data recitation, and data verification.

\section{Results and Discussion}

\subsection{Results}

RBM Cibiru Wetan was officially established in 2013. RBM CibiruWetan was formed based on the wishes of the Community Social Workers who observed a large number of people with disabilities in one hand and the non-existence of local institution that provided services to persons with disabilities.

RBM CibiruWetan is located in Pamubusan village but its office is rented and not owned. RBM conducts data collection and service delivery. Data on people with disabilities are conducted every year.

RBM has four fields. However, out of these four areas, not all of them fit the needs of persons with disabilities. There are, economy, education, health, and social.

The results of initial reflection are illustrated through the description of RBM CibiruWetan service before capacity building. The types of services in RBM CibiruWetan consist of health services, education, and jobs that are not only done by the board of RBM but also involved other parties with the hope that people with disability can fulfill their needs. However, not all types of services held by RBM CibiruWetanmet the needs of people with disabilities. When associated with the age of persons with disabilities, education is no longer a priority for them. This is becauseby obtaining decent work, people with disabilities can meet their daily needs without being dependent on others. Therefore, the board of RBM should basically pay attention to the needs of persons with disabilities so that the services provided can benefit the clients.

Before persons with disabilities get service in RBM, the service process is an important part that must be undertaken first. The process consists of stages of identifying issues faced by persons with disabilities and the process of exploring the problems and needs of persons with disabilities to know the appropriate services are provided to persons with disabilities. But in fact, the service process undertaken by the RBM board only relies on RT / RW, cadres, and families with disabilities.

The activities received by persons with disabilities as a form of available services are routine therapy, social service, involvement of persons with disabilities in election, facilitation of making e-ID card, and so forth. Activities held by RBM in accessibility services uphold the rights of persons with disabilities. Therefore, in order for this purpose to be achieved, the community must know the activities of the RBM through the preparation of a work plan tailored to the priority needs of persons with disabilities.

Not only has the work plan, RBM also has to re-manage the RBM stewardship to run in accordance with the main tasks and functions. Currently, the implementation of the RBM stewardship has not been running as it should be because not all administrators are present in the field when the activities take place.

One of skills that must be owned by the board is the skills of recording and reporting. Recording is a very important part because it is a manifestation of the accountability of activities already implemented by RBM. RBM CibiruWetan has not done the recording thoroughly.

Based on the description, it is known that $\mathrm{RBM}$ as an institution that provides services to persons with disabilities requires the development of skills for RBM board. Skill development can be supported by capacity building.

Implementation of the planning output is capacity building which includes pre-test, identification training, assessment training, service planning training, organizational management training, network training, recording training, and post-test. 
Capacity-building targets consist of RBM board, community care of persons with disabilities, and parents with disabilities. The social work method used in strengthening the capacity of social group work with the type of educational group.

The first trainingis an identification training that aims to detail issues in connection with the implementation of RBM in providing services to persons with disabilities. This is done so that RBM can identify the development of services provided to persons with disabilities, also to identify persons with disabilities who need assistance or services from RBM CibiruWetan. The result of identification training is the discovery of issues related to persons with disabilities. These issues are presented in the form of mapping the issue of persons with disabilitiesand Cibirudatabase of persons with disabilities.

The second trainingis an assessment aimed at enhancing the skills of RBM managers in understanding and exploring the problems and needs of persons with disabilities, as well as increasing the skills of RBM managers in using assessment techniques for persons with disabilities. The process of the assessment training begins with the delivery of the material. After the materials are finished, there is a discussion session to give participants an opportunity to ask questions related to the assessment. After the discussion, the resource persons invite participants to practice the techniques in the assessment. The techniques are interview and genogram.

The results of the assessment training show that the participants' skills in performing the assessment are better. Assessment training provides additional capacity to the RBM board regarding techniques in the assessment.

The outcome of this training is the availability of assessment form. The form contains the client identity format, background, problem symptoms, causal factors, client functionality dynamics, social environment, and problem focus.

The third trainingis training of service planning aimed at increasing the skill of
RBM board in making service plan to persons with disabilitiesby taking into account the aspect of the need and potency of persons with disabilities. Training of service planning begins with the giving of materials and then followed by discussion and practice.

The results of service planning training show that RBM managers learn to solve problems through discussions and develop follow-up plans by taking into account specific methods and strategies.

The fourth training is an organizational management training that aims to improve the skills of RBM managers in managing the organization and the renewal of basic tasks and functions of the RBM board adapted to the needs of persons with disabilities. The organizational management training process begins with describing the RBM first to the formation of the RBM structure.

Resource persons together with the participants explore the needs and problems of RBM primarily related to organizational management. The results of organizational management training provide skills to the $\mathrm{RBM}$ board to revitalize the RBM management structure. Decent service for persons with disabilitiesis obtained when the organization is skilled and is responsible for the main duty it has. Therefore, with the existence of organizational management training, add the skill of RBM management in arranging the stewardship structureadapted to the needs of persons with disabilities.

The fifth training is network training,aimed at enhancing the skills of RBM board members in utilizing the potential and resources available in the community, as well as improving the skills of RBM managers in managing networks that benefit the services of persons with disabilities. The process of networking training begins with the skills to link the parties who will work with RBM. Currently RBM already has several networks that assist in providing services to people with disability, but the network is still running each without any synergy. 
The results of networking training show those RBM managers are more skilled in synergy with other parties. The existence of networking training opens the minds of RBM managers to create a list of networks and develop their relevance to RBM services. Another result of this training is that RBM creates accessible source system mapping to support services for persons with disabilitiesand the linkage between one source system and other source systems. Therefore, a RBM network map is developed with other parties included in the potential and sources of social welfare.

The sixth training is a recording training aimed at increasing the skill of RBM managers in making reporting and recording regularly and clearly. The recording training process is carried out as a form of accountability of services provided by the RBM board to persons with disabilities.

The results of the recording training of RBM managers, they become skilled in managing the records and reporting done periodically as a form of evaluation and accountability of the institution. Similarly, the equipment that must be prepared in recording, give influence to the motivation of the board to write the report. The presence of the skills and motivation of the board in writing the report indirectly affect the responsibility of the board.

The description of RBM after capacity buildingindicates an increase in the management skills in providing services to persons with disabilities. This can be seen from the type of services provided by RBM to develop and refer to the needs of persons with disabilities.

The type of service that was originally tailored to the RBM stewardship area is now based on the needs of persons with disabilities and in accordance with the standards. The standards that serve as reference of RBM are to divide services into several sections, namely identification and assessment section, service and rehabilitation section, fundraising section and CSR, and referral section.

Persons with disabilities who wish to obtain services in RBM must go through a more comprehensive service process. RBM, after following capacity building,there is an improved understanding ofthe importance of identification, assessment, and planning so that this stage becomes a concern before providing services to persons with disabilities.

After persons with disabilitiesgoing through identification, assessment, and planning stages, PwDs are entitled to obtain services that meet their needs. RBM has prepared services addressed to persons with disabilities as needed. The service is presented in several activities.

The activities of RBM consist of hydrotherapy, outing, and socialization about accessibility. This shows that the $\mathrm{RBM}$ is increasingly concerned about the accessibility rights of persons with disabilitiesin CibiruWetan Village because the activities that have been designed are oriented towards the similarity of disabled person's opportunities.

The RBM board that runs RBM activities after capacity building is no longer 7 , but it increases to 12 people. The addition of a quantity of RBM boarders is expected to be proportional to the quality provided to persons with disabilities.

Skills of the board in recording after strengthening the capacity have increased. This can be seen from the reporting that has begun to be designed in the form of oral and written based on the understanding that recording and reporting important in an institution or organization. The RBM board begins reporting in writing on notebooks and social media.

The final step after implementation is evaluation, in which the evaluation is carried out on the implementation of RBM Capacity Building on Accessibility of Persons with Disabilities in CibiruWetan Village. Evaluation activities are carried out by participatory method with RBM board. The evaluation consists of evaluating the process and evaluating the results.

Evaluation process shows that capacity building of RBM CibiruWetan board runs smoothly and in accordance with pre- 
arranged activity schedule. This is supported by the presence of participants who are involved in strengthening the capacity in accordance with the targeted, so that the material submitted is complete and expected to be implemented properly. In addition, the implementation of capacity building is smoothly supported by the skills of resource persons in providing skills to the RBM board. The inhibiting factor in the implementation of capacity building is the availability of infrastructure facilities. The condition of the training venues is undeniably a bit affecting the running of capacity building activities. Another obstacle found during training is the routine of participants on Sundays to sell and gather with family, so there is a desire not to attend. However, after being given an explanation of the importance of capacity building, participants continued to follow the activity even though it was too late, thus affecting the timeliness of implementation.
Evaluation of the results shows that RBM managers who follow capacity building have skills in providing services to persons with disabilities by identifying needs and problems of persons with disabilities, assessment, planning and work matrix, improving RBM management, and recording handling cases of persons with disabilities.

Based on this, the real evidence of changes in services provided by RBM to persons with disabilities is supported by the availability of identification forms, assessment forms, RBM working matrices, the establishment of board main duty and the establishment of RBM management structure, and the formation of network maps. In addition, the RBM board also prepares diaries, process books, data books, case books, task sheets formats, databases of persons with disabilities, and proposals for documenting each case and activities undertaken. The research carried out is illustrated in the following diagram:

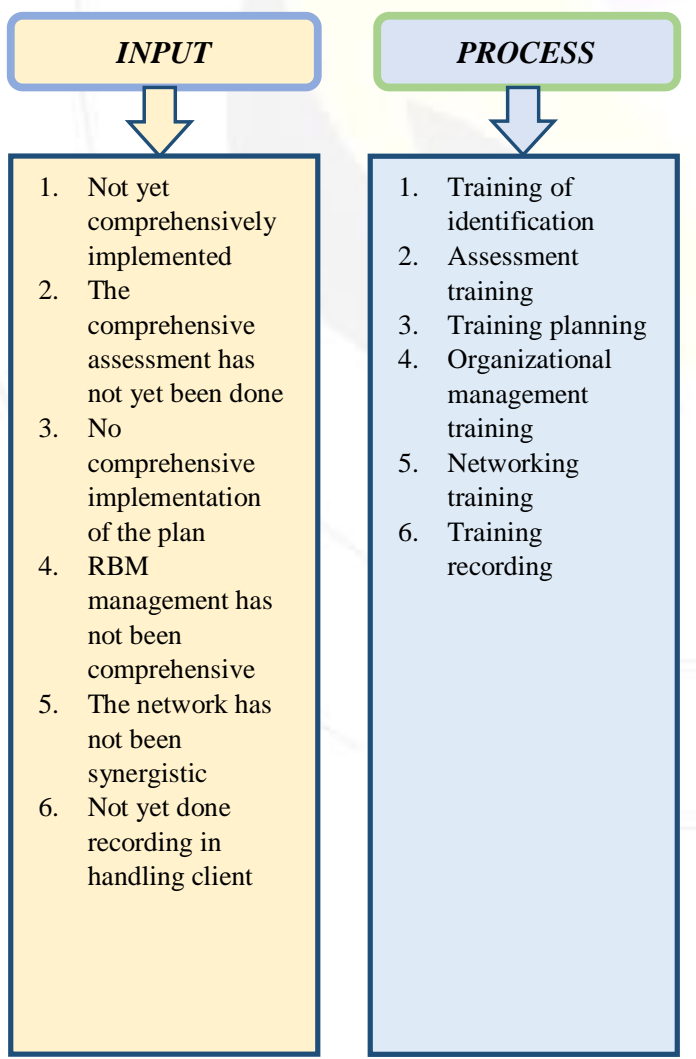

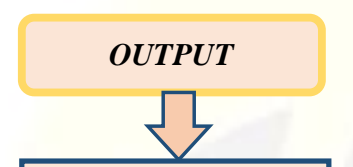

1. Conducting comprehensive identification

2. Conduct comprehensive assessment

3. Conducting comprehensive planning

4. Termanage of RBM as a whole

5. The network becomes synergistic

6. Implementation of recording in client handling

Chart 2. Model of RBM Capacity Building on Accessibility of Persons with Disabilities in Cibiru VillageWetan District Cileunyi

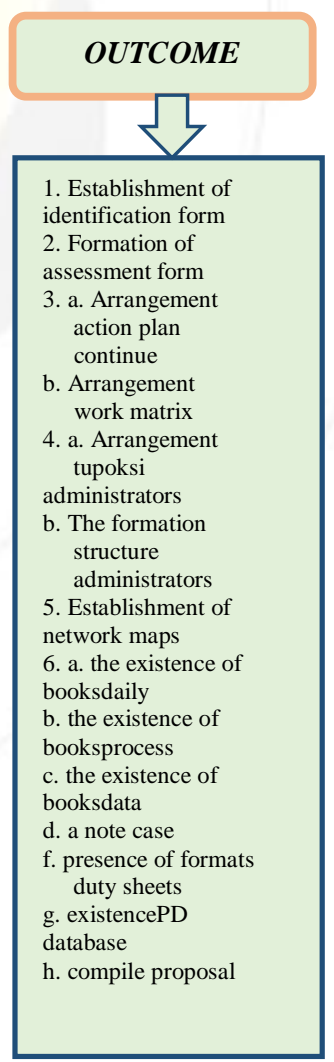

Regency 


\subsection{Discussion}

RBM CibiruWetan after obtaining capacity building, in providing services to persons with disabilitiesto provide the types of services not only therapeutic services, rehabilitation, education, health, but other services needed by persons with disabilities. Educational services are intended especially for Children with Disabilities, while for persons with disabilities will be accessible to employment, health, therapy and social rehabilitation services accessed the service agency, home therapy. The services provided by RBM are based on the needs of persons with disabilities. Persons with disabilities meet daily needs without being dependent on others. RBM as an institution that facilitates services to persons with disabilities seeks to meet these needs so that persons with disabilities can function socially as people in general.

The condition is in accordance with the findings of Yuli kurniyati (2013) that the capacity building process is an effort to increase the role of the sector in a natural institution providing services to consumers. It also demonstrates the strengthening of capacity for RBM refiners is an effort to develop the role of caretakers in the field of service work for persons with disabilities that can manifest activities that excite and expand services, and improve the performance of RBM board to achieve the objectives of the RBM meet the needs of persons with disabilities. RBM as an institution that facilitates services to persons with disabilities, seeks to meet these needs so that persons with disabilities can function socially as people in general.

In addition to the types of services that RBMs provide to persons with disabilities in accordance with the needs of persons with disabilities and thoroughly because by providing capacity building for the RBM board, the RBM, which previously only relies on information from RT / RW Heads, cadres, and families of persons with disabilities, and an understanding of the needs and problems of disability in accordance with the diversity, degree of disability of persons with disabilities. In connection with this matter RBM cibiru
Wetan provide services based on assessment and this assessment can be done by RBM managers who have Assessment Tupoksi. This is because RBM Cibiru Wetan after obtaining Strengthening the capacity already has identification form and adequate assessment. The form is designed to facilitate RBM officers in exploring the needs and problems of persons with disabilities, so that the provision of services is in accordance with existing conditions.

Another finding of this research is that for institutions that take part in the provision of services to the community and from, by, and unt to the community, capacity building is also the development of local communities through the empowerment of community members who are managers of RBM, is one of the models of increasing community participation in activities which is designed with emphasis on the learning process and empower the community through RBM which is a local institution as the added value of society from social capital (social capital) community development (Nasdian 2004). Community Based Empowerment as institutional development of the natural community in order to provide services to people with disability is an effort to develop local wisdom of Cibiru Wetan community that comes from the power of the community itself. This is the key to community empowerment.

RBM Desa Cibiru Wetan after being given capacity strengthening also shows adanyan changes in how to provide services to people with disability especially in the stages of service (client identification, assessment, planning service delivery, and interventions for people with disability.

The type of service that suits the needs of persons with disabilities should be comparable to the overall service process because with capacity building, the RBM, which was only dependent on neighbors, cadres, and families of persons with disabilities in data collection, became more directed because RBM had identification form an adequate assessment. The form is structured to facilitate RBM officers in exploring the needs of persons with 
disabilities, so that the provision of services is not provided.

A good assessment is also supported by the skills of RBM managers in digging deeper into the needs of persons with disabilities. Significant engagement is required as supporting data obtained from persons with disabilities. A good assessment will affect the planning of services provided to persons with disabilities.

Service planning is based on the results of the assessment. The skill of RBM board analysis is required in this stage because a mature and proper plan will be obtained when the RBM board is able to relate the information obtained in the assessment and tailored to the needs of persons with disabilities for the purpose to be achieved. The service planning format has been developed in strengthening the capacity, so that it will be easier for the RBM board to rebuild the planning for persons with disabilities.

Identification, assessment and planning are a series of service processes that must exist within an institution / organization in which case the agency is RBM. Therefore, RBM is expected not to override all three stages.

The result of the service process is the formation of activities to be provided to persons with disabilities. The activities will run well when the RBM officers work together and support each other. Solidarity of the board will affect the services provided. When the board lacks synergy, it affects a less comprehensive service because the service is provided partially. Persons with disabilities will feel not getting good treatment from RBM. Therefore, the implementation of main duty and cooperation and support is needed in a service.

The main duty of board that has been arranged in the basic guidence then implemented in accordance with what should be. The chairman, secretary, treasurer, identification and assessment sections, service and rehabilitation sections, the raising section and CSR, as well as the referral sections should coordinate to achieve common goals because an organization is like a system that is interconnected, has elements, and has the same goals. Therefore, the proper implementation of main duty is necessary for the continuity of RBM in the future.

Implementation of RBM board main duty can be related to the skills of RBM management in providing services to persons with disabilities. If the board of RBM has minimal skills in their respective fields then the main duty will run in sync because there will be no overlapping task, exactly what happens is complementary. The board will help each other when knowing the purpose of the organization. The board will not run alone when knowing the exact responsibilities of the tasks it has because the realization of the ability of the agency or organizational responsibilities can be seen from the extent to which its members understand the function of management.

The ability of the management skill in performing the service process (identification, assessment, planning), then organizing the activities including organizing the needs of persons with disabilities manifested in the stewardship arrangement as well as the basic guidance of $\mathrm{RBM}$, then the cooperation and support to move together to reach the objectives of $\mathrm{RBM}$, and the commitment to provide the best services for persons with disabilities, proves that RBM strives to carry out a comprehensive management function. Strengthening the capacity of the RBM board is a way to make the RBM management function comprehensive and meaningful to all RBM managers. If the $\mathrm{RBM}$ management function is running well it will indirectly affect the results of services provided to persons with disabilities.

The results will be reflected in the changes to a better direction. The change is not only physically but mentally of the board of RBM, which is related to the loyalty and dedication of the board to make RBM CibiruWetan as a useful institution for persons with disabilities.

The RBM Capacity Building model for Accessibility of Persons with Disabilities is illustrated in the following chart: 


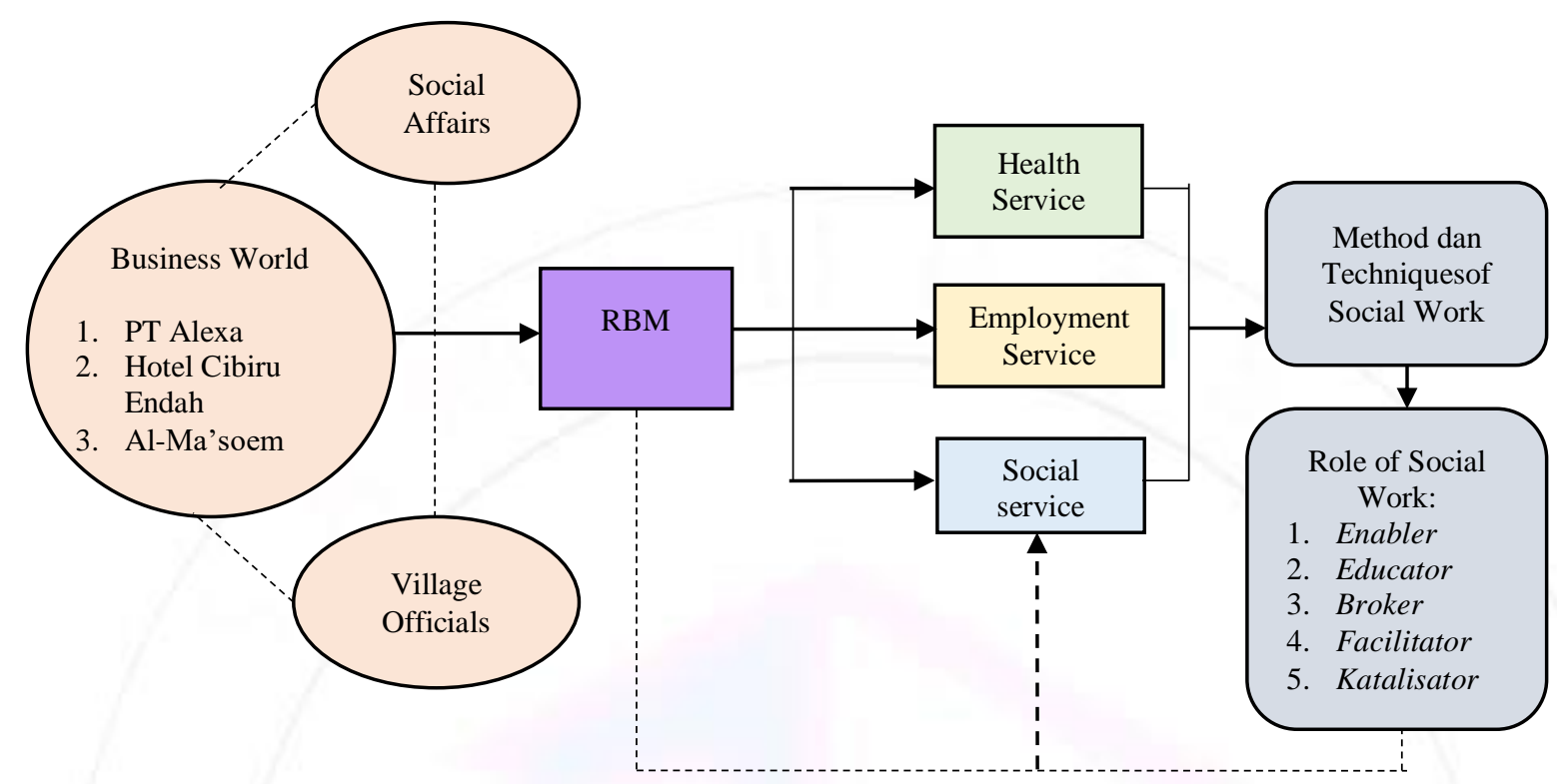

Chart 3. Model of RBM Capacity Building on Accessibility of Persons with Disabilities in Cibiru VillageWetan District Cileunyi Bandung Regency

\section{Conclusion}

RBM managers who are the subject of research are $\mathrm{FD}, \mathrm{E}$, and $\mathrm{EK}$, the three committees have the task of providing services to persons with disabilities. The three subjects have a diversity of age and education. This has an impact on the services provided to persons with disabilities; whereby the third age the subjects belong to the productive age that leads to work orientation, so that the RBM board has the motivation and energy to provide services to persons with disabilities. Educational diversity also affects the interpretation of the three boards of services provided to persons with disabilities, so that the services available and provided are based on the outcomes of RBM board members' thinking and ability to realize accessibility of persons with disabilities.

Once the RBM board has strengthened its capacity, it shows that there are changes to the RBM board, especially the types of RBM services provided to persons with disabilities in accordance with the needs of persons with disabilities. Similarly, the RBM service process, in which the ability of the RBM board in providing services to PwDs based on the results of the identification, assessment, and service planning, is done comprehensively. In addition, in the delivery of services to persons with disabilities RBM CibiruWetan compiled a work plan within one year by creating a working matrix.

RBM CibiruWetan has revitalized the RBM management structure in accordance with the needs of persons with disabilities, so that the implementation of the main tasks and functions that are formed is in accordance with the needs. RBM CibiruWetan is also now doing networking that is directed to be more integrated through the creation of a network map either with the Office or related institutions with accessibility services for persons with disabilities or with businesses that have concern for persons with disabilities.

The whole range of RBM services does not mean when there is no recording and recording proving that the RBM board has provided services to persons with disabilities. Prior to capacity building, RBM CibiruWetan has not recorded and reported on handling cases of persons with disabilities, so the skills of RBM management in this aspect need to be improved. After strengthening the capacity, changes in the ability of RBM managers in preparing the recording are visible with the 
availability of diary formats, process notes, data records, and case notes, so it is known what services have been given by RBM board to persons with disabilities.

The changes that occurred in RBM were done through the provision of capacity building which aims to improve the management skills in providing accessibility services for persons with disabilities in CibiruWetan Village. Capacity building includes identification training, assessment, service planning, organizational management, networking, and recording involving the RBM board, community care for persons with disabilities, and parents with disabilities. The method used is social group work with educational group techniques.

Changes in the RBM board indirectly affect the accessibility of persons with disabilities in CibiruWetan Village. There is an increasing skill to the RBM board in providing services to enable persons with disabilities access to health services, employment, infrastructure, and transportation.

Persons with disabilities become more accessible to health services outside of CibiruWetan Village supported by the referral field in RBM. Similarly, the accessibility of work, which with the effort to network that is integrated with the business world, provides opportunities for people with disabilities in work to improve life and livelihood.

Accessibility of infrastructure for persons with disabilities has not undergone any significant changes, especially the infrastructure available in the home of persons with disabilities. This is because families with disabilities are not fully aware of the responsibility to meet the accessibility rights of persons with disabilities. Nevertheless, RBM strives to meet the accessibility of infrastructure facilities of persons with disabilities through advocacy to families of persons with disabilities, governments and businesses, as well as transportation accessibility.

Overall, changes in RBM in the better direction occur after strengthening the capacity. Nevertheless, there are still some aspects that need to be improved in order for better services because the objectives of RBM are basically so that people with disabilities can be objectively accepted by the family and the development of public awareness and social responsibility in the effort to protect social welfare. Therefore, recommendations to various parties are needed to make better RBM in the future.

Recommendations are addressed to RBM, village government, families of persons with disabilities, and the business world in order for this research to be sustainable. The recommendations are: a) The RBM is expected to provide accessibility services to persons with disabilitiesbetter suited to the needs and problems of persons with disabilities, b) The village government through the village head is expected to support the existence of RBM by evaluating RBM's work, c) disability is expected to care about the existence of services provided by RBM to persons with disabilities, and d) Business world is expected to support RBM CibiruWetan accessibility service through Corporate Social Responsibility, so that persons with disabilitiescan be accessed with work.

\section{Reference}

Alftri. 2011. Community Development : Teori dan Aplikasi. Yogyakarta : Pustaka Pelajar

Etty Padmiati dan Sri Kuntari. 2011. Forum Rehabilitasi Berbasis Masyarakat (RBM) "Dharma Kerthi Praja Pascima": Model Pemberdayaan Masyarakat dalam Penanggulangan Penyalahgunaan NAPZA di Kota Denpasar Propinsi Bali. Jurnal Sosiokonsepsia. Vol.16, No.02

Idin Saepudin Ruhimat. 2017. Peningkatan Kapasitas Kelembagaan Kelompok Tani Dalam Pengembangan Usahatani Agroforestry: Studi Kasus Di Desa Cukangkawung, Kecamatan Sodonghilir, Kabupaten Tasikmalaya, Provinsi Jawa Barat. Jurnal Penelitian Sosial dan Ekonomi Kehutanan Vol. 14 No.1, 2017 : 1-17.

Jenivia Dwi Ratnasari, dkk. 2013. Pengembangan Kapasitas (Capacity 
Building) Kelembagaan pada Badan

Kepegawaian Daerah Kabupaten Jombang. Jurnal Administrasi Publik. Vol.1, No.3: 103-110

Jewell, Paul. 2010. Disability Ethics : a

Framework for Practitioners, Professionals, and Policy Makers. Australia : Common Ground

LexiMoleong.2007.MetodePenelitianKualita tif.Bandung: RemajaRosdaKarya

Stringer, Ernest T. 2007. Action Research. Third Edition. USA : Sage Publications Totok Mardikanto dan Poerwoko Soebiato.

2015. Pemberdayaan Masyarakat dalam Perskpektif Kebijakan Publik. Bandung : Alfabeta

Yuliati Kurniati . 2013. Penguatan Kapsitas Kelembagaan Kelompok PEW untuk Pengembangan Ekonomi Lokal Kota Yogyakarta. Jurnal Maksipreneur, Vol III. No. I . Hal 90-120. 